\title{
Spontaneous clearance of Chlamydia trachomatis accounting for bacterial viability in vaginally or rectally infected women (FemCure)
}

Citation for published version (APA):

Dukers-Muijrers, N. H. T. M., Janssen, K. J. H., Hoebe, C. J. P. A., Gotz, H. M., Schim van der Loeff, M. F., de Vries, H. J. C., Bruisten, S. M., \& Wolffs, P. F. G. (2020). Spontaneous clearance of Chlamydia trachomatis accounting for bacterial viability in vaginally or rectally infected women (FemCure). Sexually Transmitted Infections, 96(7), 541-548. https://doi.org/10.1136/sextrans-2019-054267

Document status and date:

Published: 01/11/2020

DOI:

10.1136/sextrans-2019-054267

Document Version:

Publisher's PDF, also known as Version of record

Document license:

Taverne

Please check the document version of this publication:

- A submitted manuscript is the version of the article upon submission and before peer-review. There can be important differences between the submitted version and the official published version of record.

People interested in the research are advised to contact the author for the final version of the publication, or visit the DOI to the publisher's website.

- The final author version and the galley proof are versions of the publication after peer review.

- The final published version features the final layout of the paper including the volume, issue and page numbers.

Link to publication

\footnotetext{
General rights rights.

- You may freely distribute the URL identifying the publication in the public portal. please follow below link for the End User Agreement:

www.umlib.nl/taverne-license

Take down policy

If you believe that this document breaches copyright please contact us at:

repository@maastrichtuniversity.nl

providing details and we will investigate your claim.
}

Copyright and moral rights for the publications made accessible in the public portal are retained by the authors and/or other copyright owners and it is a condition of accessing publications that users recognise and abide by the legal requirements associated with these

- Users may download and print one copy of any publication from the public portal for the purpose of private study or research.

- You may not further distribute the material or use it for any profit-making activity or commercial gain

If the publication is distributed under the terms of Article $25 \mathrm{fa}$ of the Dutch Copyright Act, indicated by the "Taverne" license above, 


\title{
Spontaneous clearance of Chlamydia trachomatis accounting for bacterial viability in vaginally or rectally infected women (FemCure)
}

\author{
Nicole H T M Dukers-Muijrers (D) , 1,2 Kevin J H Janssen (D) , ${ }^{2}$ Christian J P A Hoebe, ${ }^{1,2}$ \\ Hannelore M Götz (D) , 3,4,5 Maarten F Schim van der Loeff, ${ }^{6,7}$ Henry J C de Vries, ${ }^{6,7}$ \\ Sylvia M Bruisten (D) , ${ }^{6,7}$ Petra F G Wolffs ${ }^{2}$
}

\begin{abstract}
- Additional material is published online only. To view please visit the journal online (http://dx.doi.org/10.1136/ sextrans-2019-054267).

For numbered affiliations see end of article.
\end{abstract}

Correspondence to Dr Nicole H T M Dukers-Muijrers, Medical Microbiology, UM CAPHRI, Heerlen, Netherlands: nicole.dukers@ggdzl.nl

Preliminary results of the paper have been presented at the STI \& HIV 2019 World Congress Joint Meeting of the 23rd ISSTDR \& 20th IUSTI, Vancouver, Canada. 14-17 July 2019 (poster presentation 645).

Received 11 September 2019 Revised 23 January 2020 Accepted 28 January 2020 Published Online First 17 February 2020

\section{Check for updates}

(c) Author(s) (or their employer(s)) 2020. No commercial re-use. See rights and permissions. Published by BMJ.

To cite: DukersMuijrers NHTM,

Janssen $\mathrm{KJH}$, Hoebe CJPA, et al. Sex Transm Infect 2020:96:541-548.

\section{ABSTRACT \\ Objectives Spontaneous clearance of Chlamydia} trachomatis (CT) infections can occur between diagnosis and treatment. We followed CT patients to assess clearance using a conventional definition (no total CT-DNA, assessed by routine quantitative $P C R$ methods) and a definition accounting for viability, assessed by viability PCR testing. Methods Three outpatient STI clinics included CTdiagnosed women (The Netherlands, 2016-2017, FemCure study); participants had vaginal CT (VCT) and rectal CT (rCT) (group A: $n=155), v C T$ and were rectally untested (group B: $n=351$ ), single vCT (group $C: n=25$ ) or single rCT (group D: $n=29)$. Follow-up (median interval 9 days) vaginal and rectal samples underwent quantitative $P C R$ testing (detecting total CT-DNA). When PCR positive, samples underwent $\mathrm{V}$-PCR testing to detect 'viable $\mathrm{CT}^{\prime}$ (CT-DNA from intact CT organisms; $V$-PCR positive).

'Clearance' was the proportion PCR-negative patients and 'clearance of viable $\mathrm{CT}^{\prime}$ was the proportion of patients testing PCR negative or PCR positive but V-PCR negative. We used multivariable logistic regression analyses to assess diagnosis group (A-D), age, days since initial CT test (diagnosis) and study site (STI clinic) in relation to clearance and clearance of viable CT.

Results Clearance and clearance of viable CT at both anatomic sites were for (A) $0.6 \%$ and $3.9 \%$; (B) $5.4 \%$ and $9.4 \%$; (C) $32.0 \%$ and $52.0 \%$ and (D) $27.6 \%$ and $41.4 \%$, respectively. In multivariate analyses, women with single infections (groups $C$ and D) had higher likelihood of clearance than women concurrently infected with vCT and $\mathrm{rCT}(\mathrm{p}<0.001)$.

Of rectally untested women (group B), 76.9\% had total CT-DNA and $46.7 \%$ had viable CT (V-PCR positive) at the rectal site.

Conclusions Of untreated female vCT patients who had $\mathrm{CT}$ also at the rectal site, or who were rectally untested, only a small proportion cleared CT (in fact many had viable $\mathrm{CT}$ ) at their follow-up visit (median 9 days). Among single site infected women clearance was much higher.

Trial registration number NCT02694497.

\section{INTRODUCTION}

Chlamydia trachomatis (CT) infection is the most commonly reported treatable bacterial STI in highincome countries, with over 100 million people affected each year. ${ }^{12}$ CT disproportionally affects women in terms of its occurrence and burden of sequelae, including pelvic inflammatory disease, ectopic pregnancy, tubal infertility and chronic abdominal pain. ${ }^{3-5}$ However, spontaneous clearance of urogenital CT has been reported, ${ }^{6}$ between $19 \%-54 \%$ within 1 year $^{78}$ and 6\%-44\% between diagnosis and treatment, ${ }^{9-13}$ using quantitative PCR tests (or nucleic acid amplification tests (NAATs)). Studies on rectal clearance are scarce, reporting $18.2 \%$ in men and women $(2 / 11$; median interval 11 days $)^{14}$ and $4.0 \%(1 / 25)$ in men and $18.4 \%(7 / 38)$ in women (median interval 8 days). ${ }^{13}$ Research demonstrated lower CT bacterial load as the only determinant for clearance. ${ }^{13}$

The highly sensitive assays that are widely used for diagnosing CT detect both CT-DNA from intact CT organisms (indicative of viable CT) and CT-DNA from non-viable CT (eg, nucleic acid remnants). As current tests are unable to distinguish viable from nonviable organisms, a positive result may reflect nonviable CT. Hence, we may propose another definition of clearance to the detection of viable CT only (ie, to consider clearance having occurred when there is no more viable CT and ignore remnant bacterial DNA). Recently, we validated a PCR method for assessment of CT viability (V-PCR) in clinical swab samples. ${ }^{15} 16$ This method combines the high sensitivity and specificity of PCR with the ability to exclude detection of nucleic acid remnants from non-viable CT. It does so by incorporating a sample pretreatment step with a membrane impermeable DNA intercalating dye prior to molecular analysis blocking amplification of remnant CT-DNA from non-viable bacteria. This allows the V-PCR analyses to detect CT-DNA originating from intact (ie, viable) bacteria. Assessment of CT viability as well as evaluating both the vaginal and rectal site is vital to fill the current knowledge gaps regarding spontaneous CT clearance in women. Here, we assessed clearance of total CT-DNA and of viable CT in women diagnosed with rectal CT (rCT) or vaginal CT (vCT) (FemCure) ${ }^{17}$ when they returned to the clinic for treatment.

\section{METHODS}

Regular care STI clinic setting

The study population consisted of participants of the FemCure study, ${ }^{17}$ recruited at the STI clinics of the Public Health Services South Limburg, Rotterdam-Rijnmond and Amsterdam. The STI 
clinics apply the same procedures, using different NAATs with similar high sensitivity ${ }^{18}$ (Limburg: Roche Cobas 4800, CT/NG PCR assay (Roche Diagnostics, Basel, Switzerland); Amsterdam: Aptima combo 2 CT/NG TMA assay (Hologic Inc, San Diego, USA); and Rotterdam-Rijnmond: ProbeTec CT/NG SDA assay (BectonDickinson, Franklin Lakes, USA)). All women were tested for vaginal CT. Women were also tested rectally if they reported anal sex or anal symptoms. ${ }^{19}$ At follow-up, women with a positive rectal result were treated with a 7-day course of oral doxycycline $100 \mathrm{mg}$ twice daily. ${ }^{19}$ Women who were vaginally positive and either not rectally tested or rectally negative received a $1 \mathrm{~g}$ single oral dose of azithromycin.

\section{Study population}

Women who were diagnosed with a vaginal or a rectal CT infection (April 2016-September 2017) were included when they returned to the clinic for treatment (here called: follow-up visit). Inclusion criteria were age 18 years and older; negative for HIV, syphilis and Neisseria gonorrhoeae; no antibiotic use in the past month; and not being pregnant. ${ }^{17}$

Participants were categorised into diagnosis groups based on their initial STI clinic diagnosis: (A) vCT and rCT positive, (B) vCT positive and rCT untested, $(\mathrm{C}) \mathrm{vCT}$ positive and $\mathrm{rCT}$ negative and (D) vCT negative and rCT positive.

\section{Follow-up visit: CT-DNA and viable CT testing}

Participants self-collected samples (swabs) first at the rectal site and then at the vaginal site just prior to antibiotic treatment. These samples were analysed for the current report.

For each anatomic site, a first sample was collected for viability testing, and a second sample was collected for CT-DNA testing. The sample for viability testing was placed in $4 \mathrm{~mL}$ sucrose phosphate (2SP) transport buffer and immediately stored at $-80^{\circ} \mathrm{C}$ to maintain CT viability until laboratory analysis. The sample for CT-DNA testing was placed in COBAS buffer and used to test for total CT-DNA with PCR (Roche Cobas 4800), according to manufacturers' guidelines. Of the women who tested positive in PCR (ie, when total CT-DNA was detected), samples were subsequently tested for viability with V-PCR. A positive V-PCR test indicates presence of CT-DNA from intact (viable) CT organisms; a negative V-PCR test indicates that CT-DNA from intact (viable) CT organisms was not detected (thus indicates presence of remnant CT-DNA (non-viable CT) only). ${ }^{15} 17$

\section{Definitions of clearance}

Clearance was defined as a sample testing negative by PCR (no total CT-DNA).

Clearance of viable CT was defined as a sample testing either negative by PCR or testing positive by PCR but negative by V-PCR (non-viable CT only).

It should be noted that 'clearance' infers a transition from a positive status (a diagnosis at first visit) to a negative status (at follow-up, just prior to treatment). We acknowledge that the CT positive status was not confirmed in all women as in group B, rCT was untested. Also viable CT status was unknown at diagnosis as viability testing was not possible on the type of swabs collected in routine care. 'Clearance' is used throughout for ease of reading and clarified to address the above limitation when needed.

\section{Statistical analyses}

First, we present clearance proportions at the level of anatomical site (infection level). Second, we present proportions at patient level and separately for the diagnosis groups A-D, as these groups internationally reflect common STI clinic testing practices. We used univariable and multivariable logistic regression to evaluate the independent association between clearance outcomes and diagnosis group (A-D), age, time since initial STI clinic test (categories based on tertiles), study site (STI clinic) and self-reported history of CT, considering an overall $\mathrm{p}$ value of $\mathrm{p}<0.05$ as statistically significant (and between 0.05 and 0.07 as borderline significant). We also presented univariable analyses for education, background and number of sex partners in the last 3 months. ${ }^{17}$ We used IBM SPSS Statistics V.24 for analyses.

\section{RESULTS}

\section{Study population}

In total, 560 women participated in the FemCure study. Based on the diagnostic (first) clinic visit, 531 women had vCT (ie, groups A, B and C), and 184 women had rCT (ie, groups A and D). Group A had 155 women with vCT and concurrent rCT, group $\mathrm{B}$ had 351 women with vCT and who were rCT untested, group $\mathrm{C}$ had 25 women with single vCT (rCT negative) and group D had 29 women with single rCT (vCT negative) (online supplementary table 1). Median age was 22 years, that is, for groups A: 23 years (IQR 21-25], group B: 22 years (IQR 20-24), group C: 24 years (IQR 21-25) and group D: 25 years (IQR 22-28).

Women returned for follow-up after a median of 9 days, that is, for group A: 10 days (IQR 8-13), group B: 8 days (IQR 7-11), group C: 10 days (IQR 8-14) and group D: 10 days (IQR 8-13).

\section{Clearance of vCT in 531 vCT diagnosed women (infection level)}

Clearance was $6.0 \%$ (95\% CI 4.2 to 8.4$)$ and clearance of viable CT was $11.7 \%$ (95\% CI 9.1 to 14.7 ). In multivariable logistic regression, clearance was higher in vCT single infected women (group C), compared with women with concurrent rCT (group A), and in participants at the Rotterdam-Rijnmond clinic, compared with the Limburg clinic. Clearance of viable CT was higher in single vCT infected women (group C), in women aged 21-23 or 24 years and older, compared with women $18-20$ years and (borderline significantly higher) in women with a history of CT (table 1).

\section{Clearance of rCT in 184 rCT diagnosed women (infection level)}

Clearance was $15.8 \%$ (95\% CI 10.8 to 21.8 ) and clearance of viable CT was $35.9 \%$ (95\% CI 28.9 to 43.3 ). Clearance was borderline significantly higher in women with single rCT (group D) compared with women with concurrent vCT (group A) and in women with a history of CT (table 2).

\section{Clearance at both anatomic sites in $560 \mathrm{vCT}$ or rCT diagnosed women (patient level)}

Clearance was $6.4 \%$ (95\%CI:4.5 to 8.8$)$ and clearance of viable CT was $11.4 \%$ (95\% CI:8.9 to 14.4). In multivariable logistic regression, proportions of both outcomes were higher in rectally untested patients (group B), and substantially higher in vCT or rCT single infected women (groups C, D). Clearance was also higher in participants at the Rotterdam-Rijnmond clinic, compared with the Limburg clinic. Clearance of viable CT was higher in groups B,C, and D (compared with group A) and in women aged 21-23 years or 24 years and older (compared with 18-20 years) (table 3 ). 
Table 1 Proportions and odds ratios of clearance of total CT-DNA and clearance of viable CT at the vaginal site in 531 women who were diagnosed with vCT (FemCure)

\begin{tabular}{|c|c|c|c|c|c|c|}
\hline & Clearance of & tal CT-DNA & & Clearance of & able CT & \\
\hline & $\mathrm{n} / \mathrm{N}(\%)$ & OR $(95 \% \mathrm{Cl})$ & aOR $(95 \% \mathrm{Cl})$ & $\mathrm{n} / \mathrm{N}(\%)$ & OR $(95 \% \mathrm{Cl})$ & aOR $(95 \% \mathrm{Cl})$ \\
\hline Total & $32 / 531(6.0)$ & & & $62 / 531(11.7)$ & & \\
\hline Diagnosis group & & & & & & \\
\hline (A) vCT and $\mathrm{rCT}$ & $3 / 155(1.9)$ & $1 * * *$ & $1 * * *$ & $10 / 155(6.5)$ & $1 * * *$ & $1 * * *$ \\
\hline (B) vCT (rCT not tested) & $21 / 351(6.0)$ & $2.22(0.95$ to 10.98$)$ & $3.35(0.93$ to 12.04$)$ & $39 / 351(11.1)$ & $1.81(0.88$ to 3.73$)$ & 2.14 (0.99 to 4.62$)$ \\
\hline (C) vCT (rCT negative) & $8 / 25(32.0)$ & 23.84 (5.77 to 98.49 ) & 21.81 (4.94 to 96.27$)$ & $13 / 25(52.0)$ & 15.71 (5.70 to 43.26$)$ & $15.63(5.37$ to 45.51$)$ \\
\hline Years of age & & & & & & \\
\hline $18-20$ & $7 / 159$ (4.4) & 1 & 1 & $9 / 159(5.7)$ & $1^{*}$ & $1^{*}$ \\
\hline $21-23$ & 10/197 (5.1) & 1.16 (0.43 to 3.12$)$ & 1.20 (0.43 to 3.37$)$ & $28 / 197(14.2)$ & 2.76 (1.26 to 6.04$)$ & 2.79 (1.24 to 6.30$)$ \\
\hline$\geq 24$ & $15 / 175(8.6)$ & 2.04 (0.81 to 5.13 ) & 1.78 (0.66 to 4.78$)$ & $25 / 175(14.3)$ & 2.78 (1.26 to 6.15$)$ & 2.47 (1.07 to 5.70$)$ \\
\hline Days since initial CT diagnosis & & & & & & \\
\hline $1-7$ & $11 / 200(5.5)$ & 1 & 1 & $22 / 200(11.0)$ & 1 & 1 \\
\hline $8-11$ & $12 / 194(6.2)$ & 1.13 (0.49 to 2.63$)$ & $1.22(0.50$ to 2.97$)$ & $21 / 194(10.8)$ & 0.98 (0.52 to 1.85$)$ & 0.97 (0.49 to 1.90$)$ \\
\hline$\geq 12$ & 9/137 (6.6) & 1.21 (0.49 to 3.00$)$ & 1.42 (0.52 to 3.91$)$ & $19 / 137(13.9)$ & 1.30 (0.68 to 2.51 ) & 1.31 (0.63 to 2.73 ) \\
\hline Study site (STI clinic) & & & & & & \\
\hline Limburg & $6 / 188(3.2)$ & $1 *$ & $1^{*}$ & $17 / 188(9.0)$ & 1 & 1 \\
\hline Rotterdam-Rijnmond & $17 / 160(10.6)$ & 3.61 (1.39 to 9.38$)$ & $3.71(1.33$ to 10.33$)$ & $22 / 160(13.8)$ & 1.60 (0.82 to 3.14$)$ & 1.60 (0.77 to 3.22$)$ \\
\hline Amsterdam & 9/183 (4.9) & $1.57(0.55$ to 4.50$)$ & $1.78(0.58$ to 5.48$)$ & $23 / 183(12.6)$ & 1.45 (0.75 to 0.81$)$ & $1.49(0.71$ to 3.10$)$ \\
\hline Self-reported history of CT & & & & & & \\
\hline Yes & $15 / 151(9.9)$ & 2.36 (1.44 to 4.85$)$ & 1.55 (0.70 to 3.42 ) & $28 / 151(18.5)$ & $2.32(1.34$ to 4.00$)$ & 1.74 (0.96 to 3.15$)$ \\
\hline Not & $17 / 380(4.5)$ & $1 * *$ & 1 & $34 / 380(8.9)$ & $1 * *$ & $1 \mp$ \\
\hline Education & & & & & & \\
\hline Low & $16 / 195(8.2)$ & 1 & na & 28/195 (14.4) & $1 \neq$ & na \\
\hline Middlet & $8 / 197(4.1)$ & 0.42 (0.17 to 1.02 ) & & $20 / 197(10.2)$ & 0.57 (0.29 to 1.12$)$ & \\
\hline High & $8 / 139(5.8)$ & 0.77 (0.32 to 1.85$)$ & & $14 / 139(10.1)$ & 1.13 (0.58 to 2.22$)$ & \\
\hline Background & & & & & & \\
\hline Western & $27 / 489(5.5)$ & 1 & na & $54 / 489(11.0)$ & 1 & na \\
\hline Non-Western & $5 / 42(11.9)$ & 2.31 (0.84 to 6.36$)$ & & $8 / 42(19.0)$ & 1.90 (0.83 to 4.31$)$ & \\
\hline No. of sex partners last 3 months & & & na & & & \\
\hline 0 or 1 & 15/186 (8.1) & 1 & & $21 / 186(11.3)$ & 1 & na \\
\hline 2 or 3 & $13 / 257(5.1)$ & 0.61 (0.28 to 1.31 ) & & 29/57 (11.3) & 1.00 (0.55 to 1.84 ) & \\
\hline$\geq 4$ & $4 / 88(4.5)$ & 0.54 (0.18 to 1.69$)$ & & $12 / 88(13.6)$ & 1.24 (0.58 to 2.65 ) & \\
\hline
\end{tabular}

Clearance of total CT-DNA: at follow-up, no total CT-DNA detected at the vaginal site; clearance of viable CT: at follow-up, no total CT-DNA or only non-viable CT at the vaginal site.

${ }^{*}$ Overall $p$ value 0.01 to $<0.05,{ }^{* *}$ overall $p$ value 0.001 to $<0.01,{ }^{* * *}$ overall $p$ value $<0.001$

tThe few cases with unknown information are attributed to this category in analyses.

$\ddagger$ verall $p$ value 0.05 to $<0.07$.

This model includes diagnosisgroup, age, days since initial CT test (diagnosis), and study site (STI clinic); Cl: Confidence interval; viability polymerase chain reaction (V-PCR) is used totest for viable $\mathrm{CT}$; na: variable not entered into the multivariable model to calculateadjusted odds ratio.

aOR, OR in the multivariable analyses; $\mathrm{CT}$, Chlamydia trachomatis; OR, odds ratio in univariable analyses; $\mathrm{rCT}$, rectal Chlamydia trachomatis; vCT, vaginal Chlamydia trachomatis.

\section{Distribution of test results at follow-up (patient level)}

While some women cleared total CT-DNA (see above), most women tested PCR positive at follow-up, and many tested V-PCR positive (indicating viable infections) (table 4). The proportion of $\mathrm{vCT}$ diagnosed women testing V-PCR positive at both the vaginal and rectal site at follow-up was $62.6 \%$ in group A (concurrent rCT) and $46.7 \%$ in group B (rectally untested). Of single vCT diagnosed women ( $\mathrm{rCT}$ negative, group $\mathrm{C}$ ), $36.0 \%$ $(9 / 25)$ women rectally had CT-DNA at follow-up (two had viable $\mathrm{CT})$.

\section{DISCUSSION}

In untreated women with a vaginal or rectal CT diagnosis visiting STI clinics, we assessed the spontaneous clearance on their follow-up visit for treatment (after a median of 9 days), using a conventional definition (no total CT-DNA) and a definition accounting for viability (no CT-DNA or only remnant
CT-DNA (non-viable CT)). This is the first prospective study in a large group of women evaluating both anatomic sites within the same patient and including viability testing. We demonstrated low proportions of clearance in vCT patients who had a concurrent $\mathrm{rCT}$ diagnosis or who were rectally untested. This was in contrast to proven single site infected women of whom many showed clearance. Almost half of women who were rectally untested in regular STI clinic care showed viable CT at the rectal site at the follow-up visit.

The clearance of CT-DNA at the vaginal site $(6.0 \%$ in vCT diagnosed women; groups A, B and C) or at the rectal site $(15.8 \%$ in $\mathrm{rCT}$ diagnosed women; groups $\mathrm{B}$ and $\mathrm{D}$ ) is comparable with previous studies. ${ }^{6-14}$ Employing the definition of clearance of viable organism data increased proportions to $11.7 \%$ for the vaginal site and $39.5 \%$ for the rectal site. The higher clearance proportions observed at the rectal site (compared with the vaginal site) are notable. Possibly initial load at the rectal site is 
Table 2 Proportions and odds ratios of clearance of total CT-DNA and clearance of viable CT at the rectal site in 184 women who were previously RCT diagnosed (FemCure)

\begin{tabular}{|c|c|c|c|c|c|c|}
\hline & \multicolumn{3}{|c|}{ Clearance of total CT-DNA } & \multicolumn{3}{|c|}{ Clearance of viable CT } \\
\hline & $\mathrm{n} / \mathrm{N}(\%)$ & OR $(95 \% \mathrm{CI})$ & aOR $(95 \% \mathrm{Cl})$ & $\mathrm{n} / \mathrm{N}(\%)$ & OR $(95 \% \mathrm{CI})$ & aOR $(95 \% \mathrm{Cl})$ \\
\hline Total & 29/184 (15.8) & & & $66 / 184(35.9)$ & & \\
\hline \multicolumn{7}{|l|}{ Diagnosis group } \\
\hline (A) vCT and rCT & $21 / 155(13.5)$ & $1+$ & $1+$ & $54 / 155(34.8)$ & 1 & 1 \\
\hline (C) vCT (rCT negative) & $8 / 29(27.6)$ & $2.43(0.95$ to 6.19$)$ & $2.74(0.97$ to 7.70$)$ & $12 / 29(41.4)$ & 1.32 (0.59 to 2.97 ) & $1.34(0.57$ to 3.19$)$ \\
\hline \multicolumn{7}{|l|}{ Years of age } \\
\hline $18-20$ & $6 / 41(14.6)$ & 1 & 1 & $12 / 41(29.3)$ & 1 & 1 \\
\hline $21-23$ & $10 / 63(15.9)$ & $1.10(0.37$ to 3.30$)$ & $1.14(0.36$ to 3.57$)$ & 25/63 (39.7) & 1.59 (0.69 to 3.69$)$ & $1.67(0.70$ to 3.96$)$ \\
\hline$\geq 24$ & $13 / 80(16.3)$ & $1.13(0.40$ to 3.24$)$ & 0.96 (0.31 to 2.99$)$ & $29 / 80(36.3)$ & $1.37(0.61$ to 3.10$)$ & $1.31(0.55$ to 3.07$)$ \\
\hline \multicolumn{7}{|c|}{ Days since initial CT diagnosis } \\
\hline $1-7$ & $7 / 43(16.3)$ & 1 & 1 & $16 / 43(37.2)$ & 1 & 1 \\
\hline $8-11$ & $13 / 72(18.1)$ & $1.13(0.41$ to 3.11$)$ & 0.89 (0.30 to 2.65$)$ & $29 / 72(40.3)$ & 1.14 (0.52 to 2.48$)$ & 0.91 (0.40 to 2.06) \\
\hline$\geq 12$ & $9 / 69(13.0)$ & 0.77 (0.26 to 2.25$)$ & 0.58 (0.18 to 1.89$)$ & $21 / 69(30.4)$ & 0.74 (0.33 to 1.65$)$ & 0.57 (0.24 to 1.35$)$ \\
\hline \multicolumn{7}{|l|}{ Study site (STI clinic) } \\
\hline Limburg & $3 / 46(6.5)$ & 1 & 1 & $12 / 46(26.1)$ & 1 & 1 \\
\hline Rotterdam-Rijnmond & $6 / 35(17.1)$ & 2.97 (0.69 to 18.82$)$ & 3.66 (0.79 to 16.99$)$ & $12 / 35(34.3)$ & $1.48(0.57$ to 3.86$)$ & $1.55(0.57$ to 4.17$)$ \\
\hline Amsterdam & 20/103 (19.4) & 3.45 (0.97 to 12.28$)$ & $4.43(1.16$ to 16.91$)$ & $42 / 103(40.8)$ & 1.95 (0.91 to 4.20$)$ & 2.25 (1.00 to 5.06$)$ \\
\hline \multicolumn{7}{|l|}{ Self-reported history of CT } \\
\hline Yes & $15 / 59(25.4)$ & $2.70(1.21$ to 6.06$)$ & 2.41 (1.04 to 5.60$)$ & $26 / 59(44.1)$ & 1.67 (0.89 to 3.17$)$ & $1.57(0.81$ to 3.04$)$ \\
\hline Noł & $14 / 125(11.2)$ & $1^{*}$ & $1 *$ & $40 / 125(32.0)$ & 1 & 1 \\
\hline \multicolumn{7}{|l|}{ Education } \\
\hline Low & $8 / 57(14.0)$ & 1 & na & $20 / 57(35.1)$ & 1 & na \\
\hline Middleł & $13 / 62(21.0)$ & $1.63(0.62$ to 4.27$)$ & & $25 / 62(40.3)$ & 1.25 (0.59 to 2.63$)$ & \\
\hline High & $8 / 65(12.3)$ & 0.86 (0.30 to 2.46$)$ & & 21/65 (32.3) & 0.88 (0.42 to 1.87$)$ & \\
\hline \multicolumn{7}{|l|}{ Background } \\
\hline Western & 28/171 (16.4) & 1 & na & $62 / 171(36.3)$ & 1 & na \\
\hline Non-Western & $1 / 13(7.7)$ & 0.43 (0.05 to 3.41$)$ & & $4 / 13(30.8)$ & 0.78 (0.23 to 2.64$)$ & \\
\hline \multicolumn{7}{|c|}{ No. of sex partners last 3 months } \\
\hline 0 or 1 & $10 / 57(17.5)$ & 1 & na & $15 / 57(26.3)$ & 1 & na \\
\hline 2 or 3 & $15 / 88(17.0)$ & $0.97(0.40$ to 2.33$)$ & & $38 / 88(43.2)$ & 2.13 (1.03 to 4.39$)$ & \\
\hline$\geq 4$ & $4 / 39(10.3)$ & $0.54(0.16$ to 1.86$)$ & & 13/39 (33.3) & $1.40(0.58$ to 3.41$)$ & \\
\hline
\end{tabular}

Clearance of total CT-DNA: at follow-up, no total CT-DNA detected at the rectal site; clearance of viable CT: at follow-up, no total CT-DNA or only non-viable CT at the rectal site.

This model includes diagnosis group, age, days since initial CT test (diagnosis) and study site (STI clinic); viability polymerase chain reaction is used to test for viable CT; na (variable not entered into the multivariable model to calculate adjusted ORs).

${ }^{*}$ Overall $p$ value 0.01 to $<0.05,{ }^{* *}$ overall $p$ value 0.001 to $<0.01,{ }^{* * *}$ overall $p$ value $<0.001$

tOverall $p$ value 0.05 to $<0.07$.

$\ddagger$ The few cases with unknown information are attributed to this category in analyses.

aOR, OR in the multivariable analyses; Cl, Confidence Interval; CT, Chlamydia trachomatis; OR, OR in univariable analyses; rCT, rectal Chlamydia trachomatis; vCT, vaginal Chlamydia trachomatis.

lower, or mucosal lining cells are less susceptible to CT infection than vaginal mucosal cells. ${ }^{20} 21$

At the patient level, clearance (at both anatomic sites) was low in vCT-diagnosed women who had concurrent rCT (clearance: $0.6 \%$, clearance of viable CT: 3.9\%). Clearance was also low in vCT-diagnosed women who were rCT untested $(5.4 \%, 9.3 \%){ }^{22}$ Single vCT-infected (tested rCT negative) women, however, showed $32 \%$ clearance and $52 \%$ clearance of viable CT. It may be hypothesised that a diagnosed $\mathrm{rCT}$ is a marker for high viable CT loads at the vaginal site, when we assume that high vaginal CT loads are less likely to clear (as found previously ${ }^{13}$ ) and more likely to infect the rectal site (autoinoculation). Conversely, testing rCT negative would be a proxy for lower viable vaginal CT loads at diagnosis, with a higher likelihood of subsequent vaginal clearance. Unfortunately, we could not test this hypothesis as we did not have data on (viable) loads at diagnosis. Of note, two observations in our study (table 4) suggest autoinoculation from the vaginal to the rectal site: (1) viable CT at the rectal site was almost always observed in the copresence of viable CT at the vaginal site. (2) Of the 25 rCT negative and vCT positive patients (group C), 9 became rCT positive (6/9 reported no recent anal sex), although this observation may also hint at the oral sex hypothesis. 223

Furthermore, age of 21-23 years or 24 years and older (compared with 18-20) and history of CT were independently associated with clearance of viable infections. These findings may reflect protective immunity that developed from repeated chlamydia exposures. ${ }^{11}$ Finally, clearance proportions of vaginal total CT-DNA differed between study clinics, possibly explained by the different diagnostic NAAT tests used. Still, we consider this explanation unlikely as all used routine NAATs are highly sensitive and as STI clinics used the same NAAT for vaginal and rectal CT diagnostics (only differences in vaginal clearance were observed). Another unlikely explanation may be that clinics' served populations differed regarding their mean initial vaginal CT-DNA loads (as low load is predictive for clearance). We could not study this as information on initial CT load at time of diagnosis was unavailable.

The potential clinical implications of this study are that in the majority of female patients, visiting STI clinics, with vCT and a concurrent or untested rCT, the likelihood of clearance (median interval 9 days) is low. Thus, the risk of overtreatment 
Table 3 Proportions and ORs of clearance of total CT-DNA and clearance of viable CT at the vaginal and the rectal site in 560 women who were previously diagnosed with vCT or rCT in FemCure

\begin{tabular}{|c|c|c|c|c|c|c|}
\hline & \multicolumn{3}{|c|}{ Clearance of total CT-DNA } & \multicolumn{3}{|c|}{ Clearance of viable CT } \\
\hline & $\mathrm{n} / \mathrm{N}(\%)$ & OR $(95 \% \mathrm{CI})$ & aOR $(95 \% \mathrm{Cl})$ & $\mathrm{n} / \mathrm{N}(\%)$ & OR $95 \% \mathrm{Cl}$ & aOR $(95 \% \mathrm{Cl})$ \\
\hline & $36 / 560(6.4)$ & & & $64 / 560(11.4)$ & & \\
\hline \multicolumn{7}{|l|}{ Diagnosis group } \\
\hline (A) $\mathrm{vCT}$ and $\mathrm{rCT}$ & $1 / 155(0.6)$ & $1 * * *$ & $1 * * *$ & $6 / 155(3.9)$ & $1 * * *$ & $1 * * *$ \\
\hline (B) vCT (rCT not tested) & 19/351 (5.4) & 8.81 (1.17 to 66.43$)$ & 8.52 (1.10 to 65.96$)$ & $33 / 351(9.4)$ & $2.58(1.06$ to 6.28$)$ & $2.80(1.11$ to 7.10$)$ \\
\hline (C) vCT (rCT negative) & $8 / 25(32.0)$ & 72.47 (8.54 to 614.95$)$ & $85.45(9.49$ to 769.34$)$ & $13 / 25(52.0)$ & 26.90 (8.67 to 83.46$)$ & 28.98 (8.83 to 95.12$)$ \\
\hline (D) rCT (vCT negative) & $8 / 29(27.6)$ & 58.67 (6.98 to 492.82$)$ & 72.22 (8.18 to 637.54$)$ & $12 / 29(41.4)$ & 17.53 (5.83 to 52.71$)$ & 17.07 (5.49 to 53.10$)$ \\
\hline \multicolumn{7}{|l|}{ Years of age } \\
\hline $18-20$ & $7 / 162(4.3)$ & $1 \#$ & 1 & $7 / 162(4.3)$ & 1 ** & $1^{*}$ \\
\hline $21-23$ & $10 / 204(4.9)$ & 1.14 (0.43 to 3.07$)$ & 1.11 (0.38 to 3.21$)$ & $26 / 204(12.7)$ & $3.23(1.37$ to 7.66$)$ & 3.36 (1.36 to 8.32$)$ \\
\hline$\geq 24$ & 19/194 (9.8) & $2.40(0.98$ to 5.87$)$ & 1.58 (0.59 to 4.27$)$ & $31 / 194(16.0)$ & 4.21 (1.80 to 9.84$)$ & $3.20(1.29$ to 7.95$)$ \\
\hline \multicolumn{7}{|l|}{ Days since initial CT diagnosis } \\
\hline $1-7$ & $12 / 207(5.8)$ & 1 & 1 & 23/207 (11.1) & 1 & 1 \\
\hline $8-11$ & $16 / 205(7.8)$ & $1.38(0.63$ to 2.99$)$ & $1.58(0.68$ to 3.69$)$ & $24 / 205(11.7)$ & $1.06(0.58$ to 1.95$)$ & 1.02 (0.52 to 1.99$)$ \\
\hline$\geq 12$ & $8 / 148(5.4)$ & $0.93(0.37$ to 2.33$)$ & $0.93(0.32$ to 2.69$)$ & $17 / 148(11.5)$ & $1.04(0.53$ to 2.02$)$ & $0.92(0.42$ to 2.00$)$ \\
\hline \multicolumn{7}{|l|}{ Study site (STI clinic) } \\
\hline Limburg & $6 / 199(3.0)$ & 1 ** & 1 ** & $17 / 199(8.5)$ & 1 & 1 \\
\hline Rotterdam-Rijnmond & 19/164 (11.6) & 4.22 (1.64 to 10.82$)$ & 6.06 (2.13 to 17.25$)$ & 23/164 (14.0) & 1.75 (0.90 to 3.39$)$ & 2.09 (0.99 to 4.40$)$ \\
\hline Amsterdam & $11 / 197(5.6)$ & $1.90(0.69$ to 5.25$)$ & $2.43(0.81$ to 7.29$)$ & $24 / 197(12.2)$ & 1.49 (0.77 to 2.86$)$ & 1.63 (0.78 to 3.42$)$ \\
\hline \multicolumn{7}{|l|}{ Self-reported history of CT } \\
\hline Yes & $15 / 165(9.1)$ & $1.78(0.89$ to 3.55$)$ & 0.95 (0.44 to 2.09$)$ & $28 / 165(17.0)$ & $2.04(1.20$ to 3.47$)$ & $1.33(0.73$ to 2.42$)$ \\
\hline Noł & $21 / 395(5.3)$ & 1 & 1 & $36 / 395(9.1)$ & $1 * *$ & 1 \\
\hline \multicolumn{7}{|l|}{ Education } \\
\hline Low & $16 / 203(7.9)$ & 1 & na & $29 / 203(14.3)$ & 1 & na \\
\hline Middleł & $11 / 208(5.3)$ & $0.65(0.30$ to 1.44$)$ & & $18 / 208(8.7)$ & $0.57(0.31$ to 1.06$)$ & \\
\hline High & $9 / 149(6.0)$ & $0.75(0.32$ to 1.75$)$ & & $17 / 149(11.4)$ & $0.77(0.41$ to 1.47$)$ & \\
\hline \multicolumn{7}{|l|}{ Background } \\
\hline Western & $31 / 57(6.0)$ & 1 & na & $57 / 517(11.0)$ & 1 & na \\
\hline Non-Western & $5 / 43(11.6)$ & 2.06 (0.76 to 5.61$)$ & & $7 / 43(16.3)$ & 1.57 (0.67 to 3.69$)$ & \\
\hline \multicolumn{7}{|c|}{ No. of sex partners last 3 months } \\
\hline 0 or 1 & $15 / 195(7.7)$ & 1 & na & $21 / 195(10.8)$ & 1 & na \\
\hline 2 or 3 & $17 / 269(6.3)$ & 0.81 (0.39 to 1.66$)$ & & $31 / 269(11.5)$ & 1.08 (0.60 to 1.94$)$ & \\
\hline$\geq 4$ & $4 / 96(4.2)$ & 0.52 (0.17 to 1.62$)$ & & $12 / 96(12.5)$ & 1.18 (0.56 to 2.52$)$ & \\
\hline
\end{tabular}

Clearance of total CT-DNA: at follow no total CT-DNA detected at both anatomic sites; clearance of viable CT: at follow-up no total CT-DNA detected or only non-viable CT detected at both anatomic sites.

This model includes diagnosis group, age, days since initial CT test (diagnosis), and study site (STI clinic); viability polymerase chain reaction is used to test for viable CT; na (variable not entered into the multivariable model to calculate adjusted OR).

*Overall $p$ value 0.01 to $<0.05$, ** overall $p$ value 0.001 to $<0.01,{ }^{* * *}$ overall $p$ value $<0.001$

tOverall pvalue 0.05 to $<0.07$.

¥The few cases with unknown information are attributed to this category in analyses.

aOR, odds ratio in the multivariable analyses; Cl, Confidence Interval; $\mathrm{CT}$, Chlamydia trachomatis; OR, OR in univariable analyses; $\mathrm{rCT}$, rectal Chlamydia trachomatis; vCT, vaginal Chlamydia trachomatis.

will be very low. When one is interested to restrict treatment to viable infections only, the lower viable CT detection in single site CT-infected women and in those aged $>20$ years is notable, but these predictors lack specificity to guide treatment policy. Perhaps the most important direct implication for clinical practice can be derived from our finding that in rectally untested women (group B), 87.5\% $(n=272 / 351)$ had CT-DNA and $48.4 \%(n=170 / 351)$ had viable rectal CT at follow-up (table 4). This is indicative of large numbers of missed (viable) rectal infections when women present for vaginal CT treatment. In clinical practice, most women remain rectally untested, missing twothirds of rectal CT infections when diagnosing vCT. ${ }^{24}{ }^{25}$ It may be a problem when these rectally untested (but $\mathrm{rCT}$ positive) women are treated with azithromycin for their vCT, as azithromycin is less effective than doxycycline for $\mathrm{rCT}^{26}{ }^{27}$ In some of the Dutch STI clinics, and in some international guidelines, universal doxycycline treatment for CT infections in women has been adopted, potentially tackling the aforementioned issue. It should be noted that clinical implications of CT-DNA and viable $\mathrm{CT}$ at the rectal site (in terms of 'true infections', transmissionpotential, morbidity) are yet unknown, and we also do not know whether the clinical impact of rectal infections would be affected by the underlying route of infection (eg, autoinoculation).

This study has several limitations. (1) We did not have information on viable CT at time of initial diagnosis. V-PCR analyses is not possible on routinely collected materials as it requires a specific transport buffer and immediate storage in $-80^{\circ} \mathrm{C}$, precluding the assessment of viability in current routine clinical care diagnosis. Therefore, as in all clearance studies, the starting point was CT diagnosis by regular care tests (assessing total CT-DNA). Thus, the observed proportions of non-viable CT may be an overestimation when interpreted as the transition from viable to non-viable. (2) As in all human clearance studies, the moment of infection is unknown. 
Table 4 Distribution of CT-DNA and viable CT at the vaginal and the rectal site at the follow-up visit (just prior to treatment) a median of 9 days later, in 560 women who were previously CT diagnosed (FemCure)

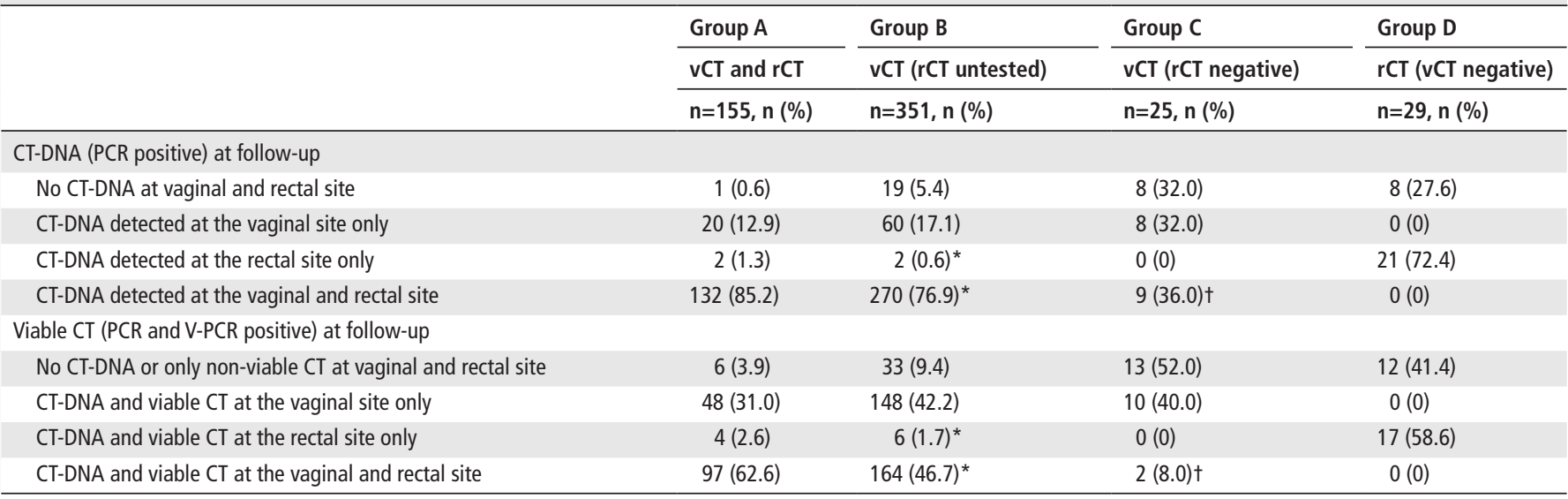

CT-DNA is assessed with a quantitative PCR; viable $C T$ is assessed with a viability PCR.

*The rectal site was initially not tested, thus could be positive or negative. The fact that at follow-up (just prior to treatment), some women rectally had CT-DNA or viable CT-DNA suggests that in those women the rectal site was initially positive (350/351 patients reported no anal sex in 2 weeks prior to treatment).

†The rectal site was initially tested CT-DNA negative. The fact that at follow-up (just prior to treatment), women rectally had CT-DNA or viable CT-DNA suggests that new infections may have occurred at the rectal site between diagnosis and treatment (6/9 patients reported no anal sex in the 2 weeks prior to treatment).

rCT, rectal Chlamydia trachomatis; vCT, vaginal Chlamydia trachomatis.

To aid interpretation, antibody detection could be useful to exclude individuals who were exposed to CT but who were not infected, ${ }^{28}$ and CT load at diagnosis could help to predict spontaneous clearance, ${ }^{13}$ but samples to collect such data were unavailable. (3) The exact day of clearance is unknown, as we did not collect daily samples. (4) Clearance may differ by genotype ${ }^{29-31}$ but genotyping was not performed on the diagnosis study samples. (5) Genotyping would also be valuable to exclude reinfections by other genotypes, as positive results at follow-up were classified as 'not cleared' or 'viable' in this study. (6) Possibly, some initial test-positive results might be false positive. Also, using a single sensitive PCR test to assess clearance could have resulted in detecting false positives or false negatives. ${ }^{32}$ 'On off effects', that is, a positive and negative test result in the same sample, might occur in samples with a low bacterial load around the detection limit. Related to this is the possibility of the initial test not being a 'true infection', but rather reflecting transient CT-DNA. This is also referred to as 'passive infection'. ${ }^{33} 34$ We could not determine to what extent such a phenomenon was present in our STI clinics population and to what extent it may have affected our

\section{Key messages}

- In the understudied population of women (560 Chlamydia trachomatis (CT) diagnosed patients), we assessed spontaneous clearance (median follow-up of 9 days) of CT infections at the vaginal and the rectal site and including viability testing.

- Women infected with CT at a single anatomic site CT had the highest likelihood to clear CT-DNA and to clear viable CT.

- In vaginal CT diagnosed female patients, clearance is low when they also were concurrently diagnosed with rectal CT or when they were rectally untested; in fact these patients commonly showed viable $\mathrm{CT}$ at both anatomic sites at follow-up.

- These findings might have diagnostic and therapeutic implications for women tested for CT. results. Furthermore, we could not estimate the duration of infection as, at diagnosis, the date of last sex (ie, exposure) was unknown. (7) The women sampled first the swab for V-PCR testing, and second the swab for PCR testing. In theory, the second swab may have had a lower bacterial load affecting clearance rates. However, we feel that such risk is minimal as the PCR test for CT-DNA test is highly sensitive. (8) We cannot entirely rule out contamination of swabs during sampling, for example, contamination of a rectal swab with vaginal secretions, despite clear written and visual instructions. (9) In the FemCure study sample, women with high education, without a previous STI or non-Western migrant background were underrepresented compared with CT infected STI clinic women. ${ }^{27}$ However, these characteristics were not associated with clearance overall, and therefore, we think that these differences do not impact the internal validity of the study. (10) Our study population was confined by exclusion criteria, such as $<18$ years or STI coinfection, so inferences to excluded subsets are not possible. (11) Caution should be taken when making population inferences from the frequency distributions of FemCure's baseline characteristics, as STI clinic populations may change over time due to policy changes. However, this may not be a substantial problem as we examined diagnosis groups, based on current testing practice. Lastly, STI clinic populations may not represent the general population.

To conclude, spontaneous clearance occurs at the vaginal and the rectal site and is more likely in women infected with CT at a single anatomic site. However, clearance is low in vCT diagnosed female patients who were concurrently diagnosed with rCT or were rCT untested. In fact, these patients commonly showed viable CT at the follow-up visit. These findings might have diagnostic and therapeutic implications for women tested for CT.

\section{Author affiliations}

${ }^{1}$ Department of Sexual Health, Infectious Diseases, and Environmental Health, South Limburg Public Health Service, Heerlen, The Netherlands

${ }^{2}$ Department of Social Medicine and Medical Microbiology, Care and Public Health Research Institute (CAPHRI), Maastricht University Medical Center (MUMC+), Maastricht, The Netherlands 
${ }^{3}$ Department of Public Health, Sexual Health Centre, Public Health Service Rotterdam-Rijnmond, Rotterdam, The Netherlands

${ }^{4}$ National Institute of Public Health and the Environment (RIVM), Epidemiology and Surveillance Unit, Centre for Infectious Disease Control, Bilthoven, The Netherlands ${ }^{5}$ Department of Public Health, Erasmus MC — University Medical Center Rotterdam, Rotterdam, The Netherlands

${ }^{6}$ Department of Infectious Diseases, Public Health Service of Amsterdam (GGD Amsterdam), Amsterdam, The Netherlands

${ }^{7}$ Amsterdam UMC, University of Amsterdam, Department of Dermatology, Amsterdam Institute for Infection and Immunity (AI\&II), Location Academic Medical Centre, Amsterdam, The Netherlands

Correction notice The article has been corrected since it was published online first. The Acknowledgement section is now included in the updated version.

Handling editor Jane S Hocking

Twitter Hannelore M Götz @GotzHannelore

Acknowledgements We are grateful to the staff at the Public Health Service (GGD) South Limburg, Lisanne Eppings, Dr. Ronald van Hoorn, Maria Mergelsberg, Mandy Sanders, Emily Suijlen, Bianca Penders, Helen Sijstermans, Julien Wijers (for data management) and Ine de Bock, the staff at GGD Rotterdam-Rijnmond, Astrid Wielemaker, Angie Martina, Roselyne Uwimana, Mieke Illidge, Klaas de Ridder, and Bram Meima (for data management), and the staff at GGD Amsterdam, Titia Heijman, Dieke Martini, Myra van Leeuwen, Claudia Owusu, Jacqueline Woutersen, Princella Felipa, Mayam Amezian, Arjdal Khadija, and Iris Deen, who are all involved in the logistics, and inclusion, Martijn van Rooijen for data management, and Anders Boyd for statistical advice. We also thank the staff at the laboratories of Medical Microbiology of the Maastricht University Medical Center, especially Judith Veugen, Laura Saelmans, and Mayk Luchessi. Also, we thank the staff of the microbiological laboratory of the GGD Amsterdam, Esther Heuser and Michelle Himschoot.

Contributors NHTMD coordinated the study, performed the statistical analyses and wrote and drafted the paper; NHTMD, CJPAH, PW, HMG, SMB, MSvdL and HDV designed the study; $\mathrm{KJHJ}$ and PW coordinated laboratory data collection and testing; all authors were involved in the study design, critically edited the manuscript and approved the final manuscript.

Funding This study is funded by a governmental organisation grant from the Netherlands Organization for Health Research and Development (ZonMW Netherlands) (registration number 50-53000-98-109).

Competing interests None declared.

Patient consent for publication Not required.

Ethics approval All participants provided written informed consent. This study was approved by the Medical Ethics Review Committee from the Maastricht University Medical Centre, Maastricht Netherlands (NL51358.068.15/METC153020, 20-012016) and monitored by the Clinical Trial Centre Maastricht.

Provenance and peer review Not commissioned; externally peer reviewed.

Data availability statement Data are available on reasonable request. Request for information on the study or for data should be sent to helen.sijstermans@ggdzl. $\mathrm{nl}$.

\section{ORCID iDs}

Nicole H T M Dukers-Muijrers http://orcid.org/0000-0003-4896-758X

Kevin J H Janssen http://orcid.org/0000-0001-5521-0521

Hannelore M Götz http://orcid.org/0000-0002-1236-6224

Sylvia M Bruisten http://orcid.org/0000-0003-4897-4261

\section{REFERENCES}

1 Unemo M, Bradshaw CS, Hocking JS, et al. Sexually transmitted infections: challenges ahead. Lancet Infect Dis 2017;17:e235-79.

2 Senior K. Chlamydia: a much underestimated STI. Lancet Infect Dis 2012:12:517-8.

3 Haggerty CL, Gottlieb SL, Taylor BD, et al. Risk of Sequelae after Chlamydia trachomatis Genital Infection in Women. J Infect Dis 2010;201:134-55.

4 Hoenderboom BM, van Benthem BHB, van Bergen JEAM, et al. Relation between Chlamydia trachomatis infection and pelvic inflammatory disease, ectopic pregnancy and tubal factor infertility in a Dutch cohort of women previously tested for chlamydia in a chlamydia screening trial. Sex Transm Infect 2019;95:300-6.

5 den Heijer CDJ, Hoebe CJPA, Driessen JHM, et al. Chlamydia trachomatis and the risk of pelvic inflammatory disease, ectopic pregnancy, and female infertility: a retrospective cohort study among primary care patients. Clin Infect Dis 2019:69:1517-25

6 Geisler WM, untreated Dof. Duration of Untreated, Uncomplicated Chlamydia trachomatis Genital Infection and Factors Associated with Chlamydia Resolution: A Review of Human Studies. J Infect Dis 2010;201:104-13.
7 Molano M, Meijer CJLM, Weiderpass E, et al. The Natural Course of Chlamydia trachomatis Infection in Asymptomatic Colombian Women: A 5-Year Follow-Up Study. $J$ Infect Dis 2005;191:907-16.

8 Morré SA, van den Brule AJC, Rozendaal L, et al. The natural course of asymptomatic Chlamydia trachomatis infections: $45 \%$ clearance and no development of clinical PID after one-year follow-up. Int I STD AIDS 2002;13 Suppl 2:12-18.

9 Geisler WM, Wang C, Morrison SG, et al. The natural history of untreated Chlamydia trachomatis infection in the interval between screening and returning for treatment. Sex Transm Dis 2008:35:119-23.

10 JOYNER JL, DOUGLAS JM, FOSTER M, et al. Persistence of Chlamydia trachomatis infection detected by polymerase chain reaction in untreated patients. Sex Transm Dis 2002;29:196-200

11 Sheffield JS, Andrews WW, Klebanoff MA, et al. Spontaneous resolution of asymptomatic Chlamydia trachomatis in pregnancy. Obstetrics \& Gynecology 2005;105:557-62.

12 Geisler WM, Lensing SY, Press CG, et al. Spontaneous resolution of genital Chlamydia trachomatis infection in women and protection from reinfection. J Infect Dis 2013:207:1850-6.

13 van Liere GAFS, Hoebe CJPA, Dirks JA, et al. Spontaneous clearance of urogenital, anorectal and oropharyngeal Chlamydia trachomatis and Neisseria gonorrhoeae in women, MSM and heterosexual men visiting the STI clinic: a prospective cohort study. Sex Transm Infect 2019:95:505-10.

14 Apewokin SK, Geisler WM, Bachmann LH. Spontaneous resolution of extragenital chlamydial and gonococcal infections prior to therapy. Sex Transm Dis 2010;37:1-4.

15 Janssen KJH, Hoebe CJPA, Dukers-Muijrers NHTM, et al. Viability-PCR shows that NAAT detects a high proportion of DNA from non-viable Chlamydia trachomatis. PLoS One 2016;11:e0165920.

16 Janssen KJH, Wolffs P, Lucchesi M, et al. Assessment of rectal Chlamydia trachomatis viable load in women by viability-PCR. Sex Transm Infect 2019:pii: sextrans-2019-054002.

17 Dukers-Muijrers NHTM, Wolffs PFG, Eppings L, et al. Design of the FemCure study: prospective multicentre study on the transmission of genital and extra-genital Chlamydia trachomatis infections in women receiving routine care. BMC Infect Dis 2016;16:381.

18 National Coordination for Infection Control (LCI). Procedure for the sexual health consultation. Available: https://lci.rivm.nl/draaiboeken/consult-seksuele-gezondheid [Accessed 4 Sep 2019].

19 Lanjouw E, Ouburg S, de Vries HJ, et al. 2015 European guideline on the management of Chlamydia trachomatis infections. Int J STD AIDS 2016;27:333-48.

20 Dukers-Muijrers NHTM, Speksnijder AGCL, Morré SA, et al. Detection of anorectal and cervicovaginal Chlamydia trachomatis infections following azithromycin treatment: prospective cohort study with multiple time-sequential measures of rRNA, DNA, quantitative load and symptoms. PLoS One 2013;8:e81236.

21 Dirks JAMC, van Liere GAFS, Hoebe CJPA, et al. Genital and anal Chlamydia trachomatis bacterial load in concurrently infected women: a cross-sectional study. Sex Transm Infect 2019;95:317-21.

22 Yeruva L, Spencer N, Bowlin AK, et al. Chlamydial infection of the gastrointestinal tract: a reservoir for persistent infection. Pathog Dis 2013;68:88-95.

23 Leenen J, van Liere GAFS, Hoebe CJPA, et al. A longitudinal study to investigate previous Chlamydia trachomatis infection as a risk factor for subsequent anorectal infection in men who have sex with men (MSM) and women visiting STI clinics in the Netherlands. Epidemiol Infect 2019;147:e214.

24 Chandra NL, Broad C, Folkard K, et al. Detection of Chlamydia trachomatis in rectal specimens in women and its association with anal intercourse: a systematic review and meta-analysis. Sex Transm Infect 2018;94:320-6.

25 Dukers-Muijrers NHTM, Schachter J, van Liere GAFS, et al. What is needed to guide testing for anorectal and pharyngeal Chlamydia trachomatis and Neisseria gonorrhoeae in women and men? evidence and opinion. BMC Infect Dis 2015;15:533.

26 Geisler WM. Diagnosis and Management of Uncomplicated Chlamydia trachomatis Infections in Adolescents and Adults: Summary of Evidence Reviewed for the 2015 Centers for Disease Control and Prevention Sexually Transmitted Diseases Treatment Guidelines. Clin Infect Dis. 2015;61:S774-84.

27 Dukers-Muijrers N, Wolffs PFG, De Vries $\mathrm{H}$, et al. Treatment effectiveness of azithromycin and doxycycline in uncomplicated rectal and vaginal Chlamydia trachomatis infections in women: a multicentre observational study (FemCure). Clin Infect Dis 2019.

28 Bakshi RK, Gupta K, Jordan SJ, et al. Immunoglobulin-Based investigation of spontaneous resolution of Chlamydia trachomatis infection. J Infect Dis 2017:215:1653-6.

29 Geisler WM, Black CM, Bandea Cl, et al. Chlamydia trachomatis OmpA genotyping as a tool for studying the natural history of genital chlamydial infection. Sex Transm Infect 2008:84:541-4. discussion 4-5.

30 Götz HM, Bom RJM, Wolfers MEG, et al. Use of Chlamydia trachomatis highresolution typing: an extended case study to distinguish recurrent or persistent infection from new infection. Sex Transm Infect 2014;90:155-60. 
31 Versteeg B, Bruisten SM, Heijman T, et al. Monitoring therapy success of urogenital Chlamydia trachomatis infections in women: a prospective observational cohort study. PLoS One 2017;12:e0185295.

32 Dukers-Muijrers NHTM, Morré SA, Speksnijder A, et al. Chlamydia trachomatis testof-cure cannot be based on a single highly sensitive laboratory test taken at least 3 weeks after treatment. PLoS One 2012;7:e34108.
33 Price MJ, Ades AE, Soldan K, et al. The natural history of Chlamydia trachomatis infection in women: a multi-parameter evidence synthesis. Health Technol Assess 2016;20:1-250.

34 Lewis J, Price MJ, Horner PJ, et al. Genital Chlamydia trachomatis infections clear more slowly in men than women, but are less likely to become established. J Infect Dis 2017;216:237-44. 